\title{
Comparison of measured Serum Total Carbon Dioxide with calculated Bicarbonate calculated from Arterial Blood Gas Analysis
}

\author{
${ }^{1}$ Thuthi Mohan, ${ }^{2} \mathrm{~B}$ Vinodh Kumar
}

\begin{abstract}
Introduction: Measured total carbon dioxide $\left(\mathrm{TCO}_{2}\right)$ from venous sample and calculated bicarbonate from arterial blood gas (ABG) have shown good agreement in some studies, while conflicting results have been obtained in few other studies. The objective of this study is to compare and assess the degree of agreement between the measured $\mathrm{TCO}_{2}$ and calculated bicarbonate and also whether they can be used interchangeably in our laboratory.
\end{abstract}

Materials and methods: We prospectively analyzed 89 ABG samples requested for calculated bicarbonate and then measured $\mathrm{TCO}_{2}$ from venous blood samples drawn simultaneously from the same participants between November 2016 and April 2017.

Results: Measured $\mathrm{TCO}_{2}$ results ranged from 5.7 to 39.9 $\mathrm{mmol} / \mathrm{L}$ (mean $23.45 \mathrm{mmol} / \mathrm{L}$ ), while calculated bicarbonate ranged from 9 to $40 \mathrm{mmol} / \mathrm{L}$ (mean $24.36 \mathrm{mmol} / \mathrm{L}$ ). The values of $\mathrm{TCO}_{2}$ and bicarbonate correlated well $(r=0.95, p<0.001)$, with the correlation given by the equation, $y=0.884 x+3.605$. The bias obtained was $-0.9 \mathrm{mmol} / \mathrm{L}$ and the standard deviation (SD) was $1.62 \mathrm{mmol} / \mathrm{L}$. The limits of agreement (LOA) were -4.1 to $2.3 \mathrm{mmol} / \mathrm{L}$, with a span of $6.4 \mathrm{mmol} / \mathrm{L}$. Out of the 89 values, $85(95.05 \%)$ were within the LOA.

Conclusion: In majority of the cases, the calculated bicarbonate concentration from $A B G$ showed a good correlation to the measured venous $\mathrm{TCO}_{2}$ concentration. Despite this excellent correlation, $\mathrm{TCO}_{2}$ did not show good agreement with calculated bicarbonate when Story and Poustie's criteria were applied, especially in cases of bicarbonate less than $20 \mathrm{mmol} / \mathrm{L}$. Hence, clinicians should be aware of this discrepancy and be cautious when using measured $\mathrm{TCO}_{2}$ and calculated bicarbonate interchangeably in the assessment and management of acid-base disorders, especially in patients with metabolic acidosis.

Keywords: Arterial blood gas, Bicarbonate, HendersonHasselbalch equation, Metabolic acidosis, Total carbon dioxide.

How to cite this article: Mohan T, Kumar BV. Comparison of measured Serum Total Carbon Dioxide with calculated

\footnotetext{
${ }^{1}$ Assistant Professor, ${ }^{2}$ Senior Resident

${ }^{1,2}$ Department of Biochemistry, ESIC Medical College \& Postgraduate Institute of Medical Sciences and Research Chennai, Tamil Nadu, India

Corresponding Author: B Vinodh Kumar, Senior Resident Department of Biochemistry, ESIC Medical College \& Postgraduate Institute of Medical Sciences and Research Chennai, Tamil Nadu, India, Phone: +919840652990, e-mail: drvinodh87@gmail.com
}

Bicarbonate calculated from Arterial Blood Gas Analysis. Indian J Med Biochem 2017;21(2):76-80.

Source of support: Nil

Conflict of interest: None

\section{INTRODUCTION}

Measurement of $\mathrm{TCO}_{2}$ is useful in determining the acidbase status of a patient. The $\mathrm{TCO}_{2}$ in serum or plasma exists in three major chemical forms: $95 \%$ as bicarbonate anion, $3 \%$ as dissolved $\mathrm{CO}_{2}$, and $2 \%$ as carbamino derivatives of plasma protein. ${ }^{1}$ Other quantitatively minor forms are carbonic acid and carbonate ions. The use of the term "bicarbonate" to describe the measured parameter is not correct since the measured $\mathrm{TCO}_{2}$ includes dissolved $\mathrm{CO}_{2}$, carbamino compounds, and carbonic acid and not strictly bicarbonate. Some laboratories use the term " $\mathrm{TCO}_{2}$ " to describe the measured bicarbonate. Two commonly employed methods to quantitate $\mathrm{TCO}_{2}$ content in serum or plasma involve acidification of the sample to convert all carbon dioxide forms to $\mathrm{CO}_{2}$ gas and measure the amount of gas formed using $\mathrm{PCO}_{2}$ electrode. The second method utilizes the enzymatic reaction of bicarbonate with phosphoenolpyruvate carboxylase coupled to a spectrophotometric indicator reaction. Most assays that specifically measure bicarbonate have reagents at an alkaline $\mathrm{pH}$. This converts other forms of $\mathrm{CO}_{2}$ to bicarbonate, so these assays are also measuring total $\mathrm{CO}_{2}$. Bicarbonate can also be calculated from blood-gas analysis using the Henderson-Hasselbalch equation. The equation used to calculate bicarbonate is $\left[\mathrm{HCO}_{3}^{-}\right]=\alpha \mathrm{PCO}_{2}(\operatorname{antilog}[\mathrm{pH}-\mathrm{pKa}])$. This equation is based on the assumption that the dissociation constant $(\mathrm{pKa})$ and solubility coefficient $(\alpha)$ are 6.1 and 0.03 respectively. However, pKa is affected by changes in $\mathrm{pH}$, ionic strength, and temperature while the values of solubility coefficient $(\alpha)$ vary with the composition of the solution, such as the presence of increased salts proteins or lipids. ${ }^{2}$ Therefore, the calculated bicarbonate values may have significant error under certain circumstances irrespective of the sample type, making the reliability questionable. Previously done studies to assess the agreement between calculated bicarbonate and measured $\mathrm{TCO}_{2}$ have shown good agreement in some studies ${ }^{3-5}$ while revealing 
conflicting results in others. ${ }^{6-8}$ The objective of this study is to compare and assess the degree of agreement between the measured $\mathrm{TCO}_{2}$ and calculated bicarbonate and also whether they can be used interchangeably.

\section{MATERIALS AND METHODS}

We prospectively analyzed 89 ABG samples requested for calculated bicarbonate and measured $\mathrm{TCO}_{2}$ from venous blood samples drawn simultaneously from the same participants between November 2016-April 2017. Out of 89 participants, 54 were males within the age range (9-68 years) and 35 were females within the age range (11-66 years). Measured $\mathrm{TCO}_{2}$ results ranged from 5.7-39.9 mmol/L (mean $23.45 \mathrm{mmol} / \mathrm{L}$ ), while calculated bicarbonate ranged from $9-40 \mathrm{mmol} / \mathrm{L}$ (mean $24.36 \mathrm{mmol} / \mathrm{L})$.

The $\mathrm{TCO}_{2}$ was analyzed in venous sample by the Vitros $\mathrm{ECO}_{2}$ Slide method in Vitros 4600 Chemistry System analyzer. ${ }^{9}$ The bicarbonate reagent slide utilizes the enzymatic method whereby the high $\mathrm{pH}$ in the spreading layer ensures that essentially all $\mathrm{CO}_{2}$ in the sample is in the bicarbonate form. The bicarbonate then diffuses to the gel layer and is used to carboxylate phosphoenolpyruvate in the presence of phosphoenolpyruvate carboxylase to form oxaloacetate and inorganic phosphate. The final reaction involves the malate dehydrogenase-catalyzed oxidation of nicotinamide adenine dinucleotide (NADH) and reduction of oxaloacetate to produce NAD+ and malate. The slide is incubated at $37^{\circ} \mathrm{C}$. The concentration of $\mathrm{CO}_{2}$ in the sample is determined by measuring the absorbance of the unreacted NADH by reflectance spectrophotometry.

Bicarbonate was calculated by the Roche Cobas b 221 Blood-Gas Analyzer using the Henderson-Hasselbalch equation. The equation used to calculate bicarbonate is as follows $\left[\mathrm{HCO}_{3}^{-}\right]=\alpha \mathrm{PCO}_{2}$ (antilog $[\mathrm{pH}-\mathrm{pKa}]$ ). This equation is based on the assumption that $\mathrm{pKa}$ is the dissociation constant for carbonic acid (equal to 6.1 for blood at $37^{\circ} \mathrm{C}$ ) and $\alpha$ is the solubility coefficient for $\mathrm{CO}_{2}$ gas (equal to 0.03 for plasma at $37^{\circ} \mathrm{C}$ ).

\section{Statistical Analysis}

The statistical analysis was performed using Microsoft Excel 2007.

(a) Paired t-test was used to compare all participants included in the study between the calculated bicarbonate from $\mathrm{ABG}$ and measured $\mathrm{TCO}_{2}$. The paired t-test was used since all parameters used in the study are numerical, all participants came from same population, and all had paired results.

(b) The comparison plot/least square linear regression analysis was used for comparison of calculated bicarbonate and measured $\mathrm{TCO}_{2}$. The values obtained by the measured $\mathrm{TCO}_{2}$ are plotted on the $y$-axis and the calculated bicarbonate from ABG is plotted on the $\mathrm{x}$-axis. A line of "best fit" is drawn in such a way that there are minimum squares of distance of all the data points from the line chosen. This line is called "least squares line". This graph/line has the following equation: $y=a+b x$; where " $y$ " is test method, where "a" is called y intercept (the point/value at which the line cuts the $y$ axis or y value).

(c) The Bland-Altman plot/difference plot was used for comparison of calculated bicarbonate and measured $\mathrm{TCO}_{2}$. This was analyzed with the averages of measured $\mathrm{TCO}_{2}$ and calculated bicarbonate on the x-axis and the differences between the two in $\mathrm{mmol} / \mathrm{L}$, plotted on the $\mathrm{y}$-axis.

\section{RESULTS}

Table 1 shows the comparison of all participants included in the study by Paired t-test, between the calculated bicarbonate from $\mathrm{ABG}$ and measured $\mathrm{TCO}_{2}$. A statistically significant difference $(\mathrm{p}<0.05)$ was observed between calculated bicarbonate from ABG and measured $\mathrm{TCO}_{2}$ when all participants included in the study independent of age, sex, and race were compared.

Graph 1 shows the comparison of calculated bicarbonate and measured $\mathrm{TCO}_{2}$ by comparison plot/least

Table 1: Comparison of all participants included in the study by paired t-test between the calculated bicarbonate and measured $\mathrm{TCO}_{2}$

\begin{tabular}{llll}
\hline & $\begin{array}{l}\text { Calculated } \\
\text { bicarbonate from } \\
A B G \text { (arterial blood) }\end{array}$ & $\begin{array}{l}\text { Measured } \\
\mathrm{TCO}_{2} \text {-venous } \\
\text { blood }\end{array}$ & p-value \\
\hline $\begin{array}{l}\text { Total no of } \\
\text { participants }\end{array}$ & 89 & 89 & $<0.001$ \\
Mean & 23.45 & & \\
SD & 7.01 & 24.36 & \\
SE & 2.48 & 6.36 & \\
\hline
\end{tabular}

SD: Standard deviation; SE: Standard error

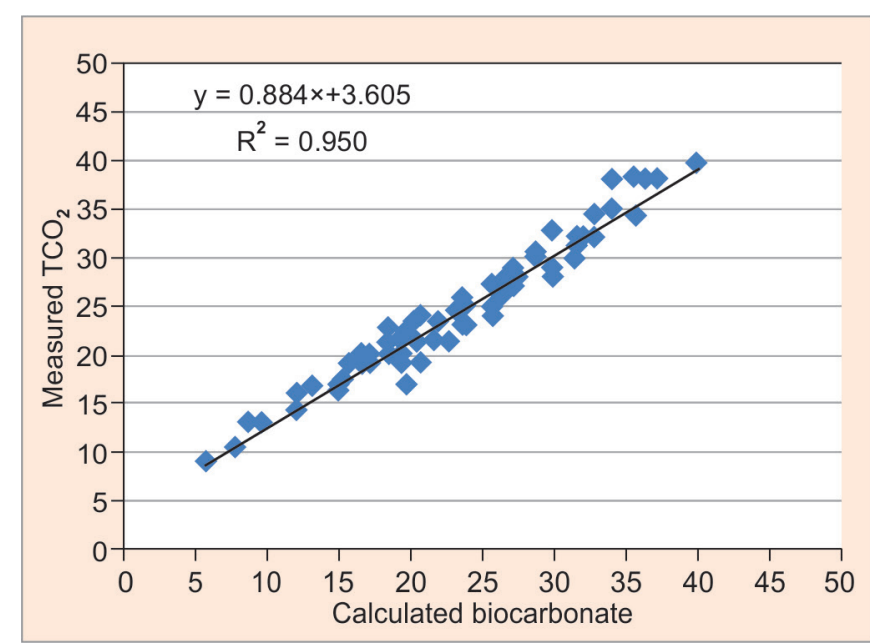

Graph 1: Comparison of calculated bicarbonate and measured $\mathrm{TCO}_{2}$ by comparison plot/least square linear regression analysis 


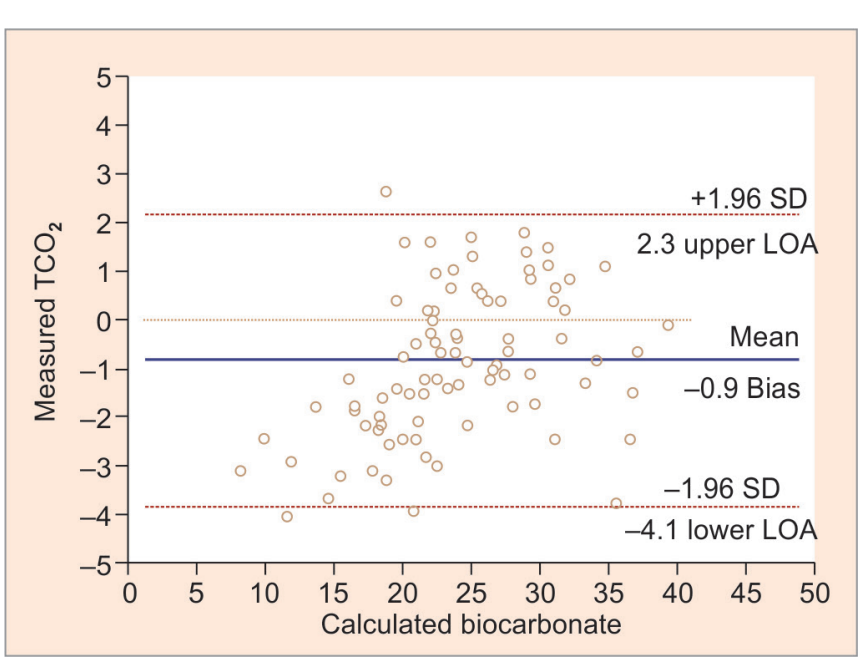

Graph 2: The Bland-Altman plot/difference plot analyzed with the averages of measured $\mathrm{TCO}_{2}$ and calculated bicarbonate on the $\mathrm{x}$-axis and the differences between the two in $\mathrm{mmol} / \mathrm{L}$ are plotted on the $y$-axis

square linear regression analysis. The values obtained by the measured $\mathrm{TCO}_{2}$ are plotted on the $y$-axis and the calculated bicarbonate from $A B G$ is plotted on the $x$-axis. Measured $\mathrm{TCO}_{2}$ results ranged from $5.7-39.9 \mathrm{mmol} / \mathrm{L}$ (mean $23.45 \mathrm{mmol} / \mathrm{L}$ ), while calculated bicarbonate ranged from $9-40 \mathrm{mmol} / \mathrm{L}$ (mean $24.36 \mathrm{mmol} / \mathrm{L}$ ). The values of $\mathrm{TCO}_{2}$ and bicarbonate correlated well $(\mathrm{r}=0.95$, $\mathrm{p}<0.001)$, with the correlation given by the equation, $\mathrm{y}=0.884 \mathrm{x}+3.605$.

Graph 2 shows the Bland-Altman plot/difference plot. This was analyzed with the averages of measured $\mathrm{TCO}_{2}$ and calculated bicarbonate on the $\mathrm{x}$-axis and the differences between the two in $\mathrm{mmol} / \mathrm{L}$, plotted on the y-axis. The upper and lower LOA were calculated from bias $\pm 1.96 \mathrm{SD}$. The span was calculated from the high limit and low limit values. The bias obtained was $-0.9 \mathrm{mmol} / \mathrm{L}$ and the SD was $1.62 \mathrm{mmol} / \mathrm{L}$. The LOA were -4.1 to $2.3 \mathrm{mmol} / \mathrm{L}$, with a span of $6.4 \mathrm{mmol} / \mathrm{L}$. Out of the 89 values, 85 (95.05\%) were within the LOA.

Table 2 shows the comparison of participants divided into 3 subgroups based on the average value of bicarbonate [ $<20 \mathrm{mmol} / \mathrm{L}$ (group I), $20-26 \mathrm{mmol} / \mathrm{L}$ (group II) and $>26 \mathrm{mmol} / \mathrm{L}$ (group III)] included in the study by paired $\mathrm{t}$-test between the calculated bicarbonate and measured $\mathrm{TCO}_{2}$. A statistically significant difference $(\mathrm{p}<0.001)$ was observed between calculated bicarbonate and measured $\mathrm{TCO}_{2}$ in the groups I and II, but a statistically insignificant $\mathrm{p}$-value ( $\mathrm{p}$-value $>0.05$ ) was observed in the group III.

Graphs 3 to 5 show the Bland-Altman plot analysis with the average value of measured $\mathrm{TCO}_{2}$ and calculated bicarbonate [ $<20 \mathrm{mmol} / \mathrm{L}$ (group I), $20-26 \mathrm{mmol} / \mathrm{L}$ (group II), and $26-40 \mathrm{mmol} / \mathrm{L}$ (group III)] on the $\mathrm{x}$-axis

Table 2: Comparison of participants divided into three subgroups based on the average value of bicarbonate $<20 \mathrm{mmol} / \mathrm{L}$ (group I), 20-26 mmol/L (group II), and $>26 \mathrm{mmol} / \mathrm{L}$ (group III) included in the study by paired t-test between the calculated bicarbonate and measured $\mathrm{TCO}_{2}$

\begin{tabular}{lllllc}
\hline $\begin{array}{l}\text { Average bicarbonate } \\
\text { (mmol/L) }\end{array}$ & $\begin{array}{l}\text { No. of } \\
\text { participants }\end{array}$ & $\begin{array}{l}\text { Mean of calculated } \\
\text { bicarbonate }\end{array}$ & Mean of measured $\mathrm{TCO}_{2}$ & Average mean & $p$-value \\
\hline$<20$ & 24 & 15.15 & 17.15 & 16.15 & $<0.001$ \\
$20-26$ & 33 & 22.34 & 22.98 & 22.66 & 0.01 \\
$>26$ & 32 & 30.83 & 31.18 & 31.01 & 0.16 \\
\hline
\end{tabular}

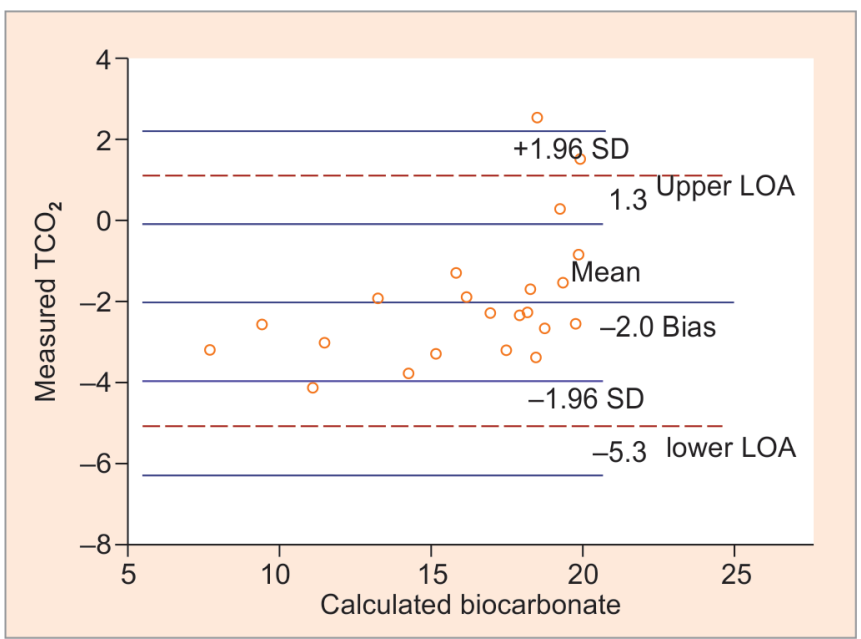

Graph 3: The Bland-Altman plot analysis with the averages of measured $\mathrm{TCO}_{2}$ and calculated bicarbonate $(<20 \mathrm{mmol} / \mathrm{L})$ on the $\mathrm{x}$-axis and the differences between the two in $\mathrm{mmol} / \mathrm{L}$ are plotted on the $y$-axis

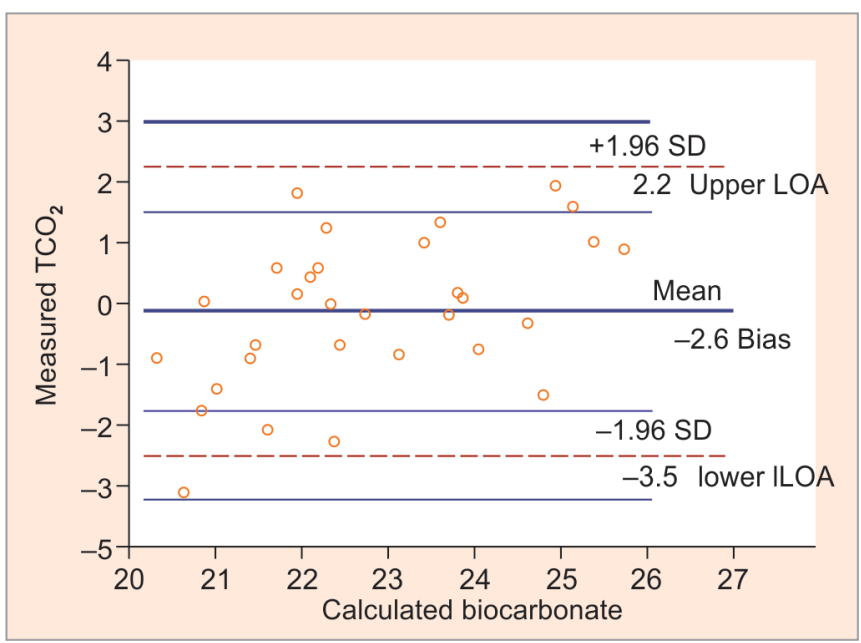

Graph 4: The Bland-Altman plot analysis with the averages of measured $\mathrm{TCO}_{2}$ and calculated bicarbonate $(20-26 \mathrm{mmol} / \mathrm{L})$ on the $\mathrm{x}$-axis and the differences between the two in $\mathrm{mmol} / \mathrm{L}$ are plotted on the $y$-axis 


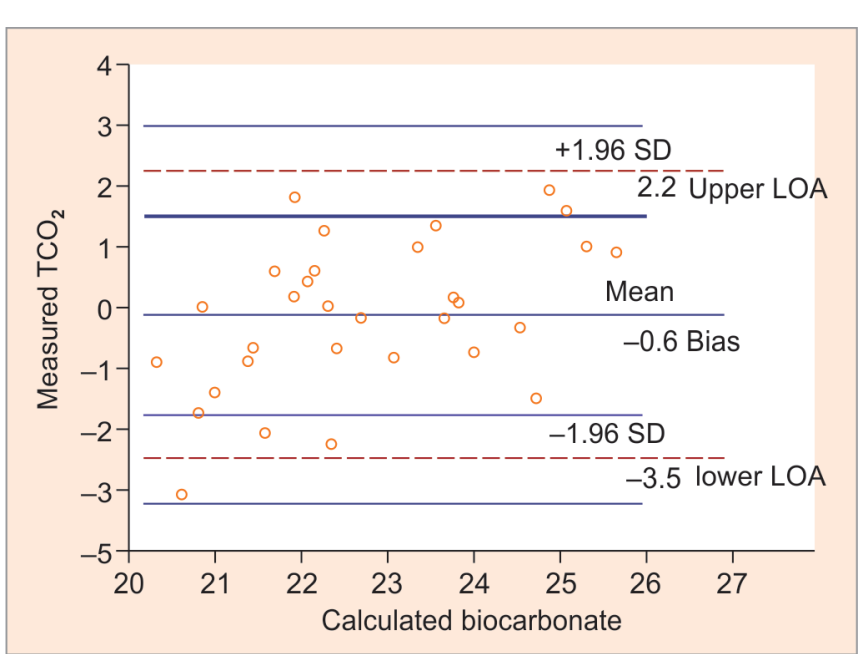

Graph 5: The Bland-Altman plot analysis with the averages of measured $\mathrm{TCO}_{2}$ and calculated bicarbonate $(>26 \mathrm{mmol} / \mathrm{L})$ on the $\mathrm{x}$-axis and the differences between the two in $\mathrm{mmol} / \mathrm{L}$ are plotted on the $y$-axis

and the differences between the two in $\mathrm{mmol} / \mathrm{L}$ plotted on the $y$-axis respectively.

\section{DISCUSSION}

The agreement between calculated bicarbonate from venous sample and measured $\mathrm{TCO}_{2}$ from $\mathrm{ABG}$ have shown good agreement in some studies ${ }^{3-5}$ while revealing conflicting results in others. ${ }^{6-8}$ The objective is to find out whether the values obtained by both the methods can be used interchangeably in our laboratory.

Theoretically measured $\mathrm{TCO}_{2}$ is slightly higher than calculated bicarbonate. This is because the measured $\mathrm{TCO}_{2}$ includes an additional nonbicarbonate $\mathrm{CO}_{2}$ component which amounts to around $1.2 \mathrm{mmol} / \mathrm{L}$. The other reason is that the serum or plasma sample used to measure $\mathrm{TCO}_{2}$ is derived from venous blood, which in itself has a slightly higher bicarbonate concentration than that of the arterial blood. These theoretical reasons in themselves amount to approximately $2.0 \mathrm{mmol} / \mathrm{L}$ difference between calculated and measured bicarbonate. ${ }^{10-12}$

The first step in assessing agreement between measured and calculated bicarbonate by correlation coefficient showed a good correlation with $\mathrm{r}=0.950$ with $\mathrm{p}<0.05$. The correlation coefficient to assess the agreement depends not only on the correlation coefficient, but also on the range of values, so a wide range of values will show a good correlation even if the values are in poor agreement.

By Bland-Altman analysis, the bias and SD obtained were -0.9 and $1.62 \mathrm{mmol} / \mathrm{L}$ respectively. The LOA were -4.1 to $2.3 \mathrm{mmol} / \mathrm{L}$, with a span of $6.4 \mathrm{mmol} / \mathrm{L}$. Out of the 89 values, 85 (95.05\%) were within the LOA. Then Story and Poustie's criteria were used to assess the degree of agreement between calculated bicarbonate and measured $\mathrm{TCO}_{2}{ }^{13}$ The criteria proposed for agreement are: (i) The bias or difference between calculated $\mathrm{TCO}_{2}$ and measured bicarbonate should be less than $\pm 1 \mathrm{mmol} / \mathrm{L}$, (ii) the LOA between the methods should range within a bias $\pm 2 \mathrm{mmol} / \mathrm{L}$ or within a total span of $4 \mathrm{mmol} / \mathrm{L}$, to be clinically insignificant. The results of our study showed a bias of $-0.9 \mathrm{mmol} / \mathrm{L}$, which fulfilled the first criteria, but the LOA were -4.1 to $2.3 \mathrm{mmol} / \mathrm{L}$, with a span of 6.4 $\mathrm{mmol} / \mathrm{L}$, which did not fulfill the second criteria. Despite good statistical correlation obtained by paired t-test and linear regression analysis, the application of criteria proposed by Story and Poustie for agreement between $\mathrm{TCO}_{2}$ and $\mathrm{HCO}_{3}$ is not fully satisfied.

The participants were subgrouped into three groups based on the average value of measured $\mathrm{TCO}_{2}$ and calculated bicarbonate as follows, average bicarbonate $<20 \mathrm{mmol} / \mathrm{L}$ (group I), 20-26 mmol/L (group II) and $26-40 \mathrm{mmol} / \mathrm{L}$ (group III) independent of age and sex. On application of the criteria of Story and Poustie, the first subgroup did not fulfill both the criteria but the 2nd and 3rd subgroups fulfilled the first criteria, but not the second criteria. Hence, the poor agreement between the two methods was observed at lower bicarbonate concentration, especially at bicarbonate concentration at $<20 \mathrm{mmol} / \mathrm{L}$.

The discrepancy in values between measured $\mathrm{TCO}_{2}$ and calculated bicarbonate can be explained because of usage of a constant pKa of 6.1 in the HendersonHasselbalch equation, i.e., used to calculate the bicarbonate. The study of Flear et $\mathrm{al}^{14}$ showed that $\mathrm{pKa}$ values varied considerably by more than 0.06 in healthy volunteers and in very ill patients and hence, an error of approximately $\pm 60 \%$ was noted in calculated bicarbonate based on constant pKa of 6.1. Another study by O'Leary and Langton found a significant decrease of the $\mathrm{pKa}$ in patients considered to have metabolic acidosis when compared with patients with bicarbonate concentration within the reference interval. ${ }^{6}$ The findings in our study also noted that majority of values falling outside the LOA occurred at bicarbonate concentration $<20 \mathrm{mmol} / \mathrm{L}$, which seem to be in agreement with $\mathrm{O}^{\prime}$ Leary and Langton.

The other cause of discrepancy in results could be due to preanalytical factors, such as sample collection and handling like inadequate mixing, acidification, nonmaintenance of anaerobic condition, and dilution of ABG samples with excess heparin that can decrease the $\mathrm{pH}$ and $\mathrm{pCO}_{2}$, and, hence, will affect the bicarbonate values. ${ }^{6,7}$ The clinicians would prefer instantly the calculated bicarbonate results from the ABG instrument placed in the ICU for the management of acid-base disorders, rather than sending for measured $\mathrm{TCO}_{2}$ to the laboratory. But the findings of poor agreement would have an impact on the utility of calculated bicarbonate by the clinicians, especially, in 
patients with metabolic acidosis. Parameters which are calculated using bicarbonate concentration like base excess and anion gap may also be affected by this discrepancy.

\section{CONCLUSION}

In the majority of cases, the calculated bicarbonate concentration from ABG showed a good correlation to the measured venous $\mathrm{TCO}_{2}$ concentration. Despite the statistical correlation, $\mathrm{TCO}_{2}$ did not show good agreement with calculated bicarbonate when Story and Poustie criteria were applied, especially in cases of bicarbonate less than $20 \mathrm{mmol} / \mathrm{L}$. Hence, it is necessary to be cautious when using measured $\mathrm{TCO}_{2}$ and calculated bicarbonate interchangeably in the assessment and management of acid-base disorders, especially in patients with metabolic acidosis.

\section{REFERENCES}

1. Davenport HW. The ABC of acid-base chemistry. 5th ed. Chicago: University of Chicago Press; 1969. p. 34.

2. Scott MG, Klutts JS. Electrolytes and blood gases. In: Burtis CA, Ashwood ER, Bruns DE, editors. Tietz textbook of clinical chemistry and molecular diagnostics. 4 th ed. St. Louis (MO): Saunders; 2006. p. 983-1018.

3. Kumar V, Karon BS. Comparison of measured and calculated bicarbonate values. Clin Chem 2008 Sep;54(9):1586-1587.

4. Chittamma A, Vanavanan S. Comparative study of calculated and measured total carbon dioxide. Clin Chem Lab Med 2008;46(1):15-17.
5. Ungerer JP, Ungerer MJ, Vermask WJ. Discordance between measured and calculated total carbon dioxide. Clin Chem 1990 Dec;36(12):2093-2096.

6. Story DA, Poustie S, Bellomo R. Comparison of three methods to estimate plasma bicarbonate in critically ill patients: Henderson-Hasselbalch, enzymatic and strong-ion-gap. Anaesth Intensive Care 2001 Dec;29(6):585-590.

7. Lolekha PH, Boonlert W, Kost GJ, Vanavanan S, Lolekha S. Comparative study of values of calculated bicarbonate and measured total carbon dioxide content. Point Care 2003 Jun;2(2):135-143.

8. O'Leary TD, Langton SR. Calculated bicarbonate or total carbon dioxide? Clin Chem 1989 Aug;35(8):1697-1700.

9. Fezzotti A, Gambini AM, Coppa G, De Sio G. Total carbon dioxide measured by the Vitros enzymatic method. Clin Chem Lab Med 1998 Jan;36(1):43-46.

10. Kelly AM, McAlpine R, Kyle E. Agreement between bicarbonate measured on arterial and venous blood gases. Emerg Med Australas 2004 Oct-Dec;16(5-6):407-409.

11. Middleton P, Kelly AM, Brown J, Robertson M. Agreement between arterial and central venous values for $\mathrm{pH}$, bicarbonate, base excess and lactate. Emerg Med J 2006 Aug;23(8): 622-624.

12. Malatesha G, Singh NK, Bharija A, Rehani B, Goel A. Comparison of arterial and venous $\mathrm{pH}$, bicarbonate, $\mathrm{pCO} 2$ and pO2 in initial emergency department assessment. Emerg Med J 2007 Aug;24(8):569-571.

13. Story DA, Poustie S. Agreement between two plasma bicarbonate assays in critically ill patients. Anaesth Intensive Care 2000 Aug;28(4):399-402.

14. Flear CT, Roberts SW, Hayes S, Stoddart JC, Covington AK. pK1' and bicarbonate concentration in plasma. Clin Chem 1987 Jan;33(1):13-20. 